\title{
Experimental Methods to Monitor the Production and Quality of Eggs of Captive Marine Fish
}

\author{
Anders Thorsen \\ Institute of Marine Research, P. O. Box 1870 \\ Nordnes, 5817 Bergen, Norway \\ Edward A. Trippel \\ Fisheries and Oceans Canada, Biological Station \\ St. Andrews, New Brunswick, Canada E5B 2L9 \\ Yvan Lambert \\ Ministère des Pêches et des Océans, Institut Maurice-Lamontagne \\ C. P. 1000, Mont-Joli, Québec, Canada G5H 3 Z4
}

\begin{abstract}
We review and recommend a variety of methods used to conduct experiments on egg production of marine fishes in the laboratory. Aspects assessed include (i) domestication of wild fish, (ii) holding facilities and handling, (iii) broodstock diet, (iv) tagging of fish (v) monitoring maturation, (vi) feeding during spawning, (vii) spawning conditions, (viii) egg collection techniques, (ix) spawning fish and stress, (x) artificial fertilization, (xi) initial egg sample analysis, and (xii) egg and larval quality and mortality. Careful consideration should be given to proper experimental design and the deployment of appropriate techniques to measure maternal reproductive output of captive fish, as results can be easily influenced by inadequate attention to laboratory protocol. Emphasis is given to commercially important species of the North Atlantic particularly gadoids, though the practices described presumably have broader application.

Keywords: broodstock, cod, fecundity, egg, marine fish, larvae, maturation, mortality, spawning.
\end{abstract}

\section{Introduction}

The relationship between the characteristics of parent fish, the number of eggs produced, and the actual number of progeny that reach maturity is fundamental to the investigation of fish recruitment. Survival of offspring is dependent on a variety of factors. For example, during early ontogeny, embryos or yolk sac larvae may die due to physiological or developmental problems, which in some cases can contribute to significant losses (Kjørsvik and Lønning, 1983; Kjørsvik et al., 1990; Solemdal, 1997; Makhotin et al., MS 2001). Predation on eggs and larvae also strongly influence recruitment (Melle, 1985; Rothschild, 1986; Vallin et al., 1999; Bishop and Green, 2001).

Egg quality and associated offspring survival is an area of recent interest in recruitment studies. Egg quality is influenced by a variety of female characteristics such as genetics, stress, condition, body size, reproductive experience and with the exception of genetics, these traits are subject to natural annual variation (Hjort, 1914; Holst, MS 1996; Marshall et al., 1998; Cardinale and Arrhenius, 2000; Lloret and Ratz, 2000; Yaragina and Marshall, 2000). Egg size is the simplest and most widely used measure of egg quality. For example, comparative egg dry weight among individual Atlantic cod (Gadus morhua) may vary by more than a factor of two (Ouellet et al., 2001; A. Thorsen, unpubl. data). Egg size differences of this magnitude influence the size of larvae produced (Knutsen and Tilseth, 1985; Gisbert et al., 2000; Zhao et al., 2001) and may thereby alter the probability of survival during sensitive early life stages. Field data indicate that there is a positive correlation between egg size and larval survival in some years (Meekan and Fortier, 1996), this has however been difficult to confirm under laboratory conditions (Thorpe et al., 1984; Gisbert et al., 2000; Jónsson and Svavarsson, 2000; Ouellet et al., 2001; Zhao et al., 2001). 
Knowledge of the processes that influence fecundity and egg quality is important for the understanding of recruitment of marine fishes. It can also have direct practical use in fish stock assessment. In some species data on individual fecundity are integrated with planktonic egg surveys to estimate spawning stock biomass (Armstrong et al., 2001), which in turn is used to establish fishing quotas.

The majority of commercial marine fish species are batch spawners that release pelagic eggs (Murua and Saborido-Rey, 2003). Batch spawning implies that an individual spawns over a protracted period of time and that the number and size of eggs released in each batch varies over the spawning season (Hislop et al., 1978; Kjesbu, 1989; McEvoy and McEvoy, 1991; Trippel, 1998).

The potential fecundity of many fish species can be estimated by counting the number of maturing (vitellogenic) oocytes present in the ovary before spawning. However, oocytes can be broken down by the follicle cell layers and reabsorbed through a process known as follicular atresia. Atresia can affect ripening oocytes during recruidesence (Witthames and Greer Walker, 1995; Kurita et al., 1999; Rideout et al., 2000; Hardardottir, MS 2001) as well as throughout spawning (Witthames and Greer Walker, 1995; Hardardottir, 2001). Some fish species, such as sand sole (Pergusa lascaris) and northern anchovy (Engraulis mordax), continue to recruit oocytes into vitellogenesis throughout the spawning season and are known as indeterminate spawners. The lack of a clear separation in oocyte size between immature and maturing oocytes makes it difficult to estimate potential fecundity for these species.

The number of oocytes that mature and spawn is referred to as realized fecundity. To collect information on realized fecundity, batch number and egg quality, it is often necessary to conduct studies on spawning fish in the laboratory. Laboratory studies on captive fish enable the monitoring of egg production of individual females, revealing specific physiological processes related to spawning and reproductive potential that cannot be studied appropriately in the wild. To improve the quality of research, and ease the comparison of results between studies, it is important to develop guidelines and standard protocols that can be adapted by a number of investigators in this growing area of fishery science. With this aim, we describe and evaluate some of the common experimental procedures applied to date to study the reproduction of marine fishes in experimental conditions. Aspects reviewed include (i) domestication of wild fish, (ii) holding facilities and handling, (iii) broodstock diet, (iv) tagging of fish (v) monitoring maturation, (vi) feeding during spawning, (vii) spawning conditions, (viii) egg collection techniques, (ix) spawning fish and stress, (x) artificial fertilization, (xi) initial egg sample analysis, and (xii) egg and larval quality and mortality. The procedures described are those used in the fish reproduction laboratories at the Institute of Marine Research in Bergen, Norway (abbreviated as IMR), the Biological Station in St. Andrews, New Brunswick, and Institut Maurice-Lamontagne, Mont Joli, Québec, Canada.

\section{Domestication of Wild Fish}

During laboratory experiments, environmental conditions, nutrition, fish behaviour, and exercise will differ from the natural environment. This may reduce the validity of extrapolating results obtained on captive animals to wild populations. For example, Atlantic cod maintained under typical aquaculture conditions from the egg stage usually attain much higher condition, and reach sexual maturity at earlier ages and smaller sizes than wild fish (Bergstad et al., 1987; Svåsand et al., 1996). Although often ineffective, it is common to regulate feeding and modify tank conditions in order to reduce the effect of fish domestication. The domestication effect can also be minimized by keeping fish in captivity only long enough to conduct the experimental work (Lambert and Dutil, 2000). However, capture and transport to the laboratory is very stressful. Collected fish need to be given time to acclimate to tanks and, eventually, to feed normally before an experiment is initiated. Experimental protocol for different studies indicate that acclimation of wild Atlantic cod, haddock (Melanogrammus aeglefinus), flatfishes and herring (Clupea harengus) to captivity usually requires 1-4 months (Hislop et al., 1978; Dutil et al., 1992; Ma et al., 1998; Watanabe et al., 2001). Shortly after collection, fish typically have a depressed appetite and may starve and those with depleted energy reserves at capture (e.g. post spawning) may not recover (A. Thorsen, unpubl. observations). Therefore, it may be preferable to collect wild fish for spring-spawner broodstock during the summer or autumn feeding periods.

\section{Holding Facilities and Handling}

Fish species have varying requirements for tank volume, water quality, and light intensity. Husbandry requirements for various established and candidate aquaculture species can be found in standard aquaculture textbooks (Lekang and Fjæra, 1997; Willoughby, 1999). Tank volume and recommended fish densities are dependent on tank shape and water cur- 
rent. It is probably important for constantly swimming pelagic fish such as herring and mackerel (Scomber scombrus) to be able to swim without having to constantly stop and turn.

Most land-based tanks used by the aquaculture industry are circular, with a centrally located bottom drain and a water supply entering the tank from the side-wall. Such tanks have one-way water currents, uniform water quality, and are effective in removing feces and small particles of uneaten food.

Sea cages consisting of mesh netting are often used for holding marine fish prior to and sometimes during the breeding period. Large plastic bags have also been utilized (e.g. $6 \mathrm{~m}$ depth, $6 \mathrm{~m}$ diameter, $160 \mathrm{~m}^{3}$ ). Net cages are practical and work well in most situations. However, net cages do not allow the same degree of environmental control as land-based tanks or floating bags, especially with regard to water current, light intensity, photoperiod, salinity and temperature. Among these, photoperiod and water temperature are believed to play important roles in the maturation cycle of many fish species (Middaugh et al., 1992; Taranger et al., 1998; Smith et al., 1999).

Demersal fish species are rarely exposed to direct sunlight in their natural environment. Exposure to bright lighting may make it difficult for species to acclimate to shallow sea cages or uncovered outdoor land-based tanks. In Atlantic cod, initiation of sunburn is marked by the appearance of pale spots on the dorsal surface of the head and back (Senstad, 1990). In order to reduce sun exposure, use of a shade net on top of the sea cage or tank is recommended. Such shade nets are commercially available from suppliers of aquaculture equipment and can be ordered with predefined values of light reduction. A commonly used shade net for example, reduces light intensity by $70 \%$. At the same time these shade nets allow for a natural light cycle. For tanks, an alternative to shade netting is to use a cover in combination with an artificial light source that can be adjusted for natural photoperiod. A tank cover, with a small circular hole $(\sim 15 \mathrm{~cm}$ diameter $)$ in the center, has also been used successfully to limit light intensity, and maintain natural photoperiod.

Many reproductive experiments require the monitoring of body size over time. Frequent handling may cause stress or induce injuries to fish. Atlantic herring, for example, may lose numerous scales when handled. As an alternative, random sub-samples of fish can be sacrificed for detailed body measurements (Ma et al., 1998). This has the advantage of allowing the internal organs to be weighed and analyzed, but often requires a high number of experimental fish. Atlantic cod and some flatfish can be handled with much lower risk of injury. For these species, it is more common to use individually tagged fish which are monitored over time.

Body measurements and tagging usually require use of anesthetics. A variety of anesthetics have been used for research purposes (Mattson and Riple, 1989). For Atlantic cod, metomidate (5 mg per litre seawater) was proven to be the best anestethetic although benzocaine (100 mg per ml stock solution; 10-15 ml per litre seawater) and MS-222 (75 mg per litre) were also acceptable alternatives (Mattson and Riple, 1989; A. Thorsen, unpubl. observations). Recovery time with metomidate is longer than for benzocaine but the safety margins are higher. Fish can be left in the anesthetic for a longer time since respiration is much less depressed with metomidate compared to benzocaine. However, metomidate is expensive and has sometimes been commercially unavailable. In addition, it is regarded as a hypnotic drug (induces sleep), and thus its use is questionable in surgical procedures.

The anesthetic is usually diluted in a small tank (e.g. 50 litre seawater). Oxygen is continuously bubbled into the tank water. Fish are left in the tank for 25 min until they do not react when held in the caudal region. Following measurements, fish are transferred to another tank with fresh seawater, where they normally recover within 3-5 min. However, if ventilation of the gills through opercular movements is not restored, gills should be flushed by circulating seawater through the mouth or by moving the fish back and forth in the water with a grip around the caudal peduncle. Fish may have more problems being revived from the anesthetic during the spawning period than other times of the year (A. Thorsen, unpubl. data).

\section{Broodstock Diet}

Fish growth rate and condition can have a large impact on egg production (Kjesbu et al., 1991; Karlsen et al., 1995; Kjesbu and Holm, 1994; Kjesbu et al., 1998). In order to produce broodstock with condition factors representative of wild fish it is necessary to regulate food quantity and quality (Kjesbu et al., 1991; Lambert and Dutil, 2000). Exercise has also been explored as a method to control growth rate and condition (Karlsen et al., 1999). When trying to mimic situations in the wild, food rations used for aquaculture purposes should be avoided, since they will usually result in much higher growth rates and condition factors than those of wild fish. Research on Atlantic cod at IMR has recommended two feedings per week of commer- 
cial dry pellets ( $10 \%$ lipid content) at a level of $0.3 \% \mathrm{~kg}$ per fish per day. For Atlantic herring, rations of 1 and 3 $\mathrm{g}$ frozen krill per fish per day (average weight of fish $250 \mathrm{~g}$ ) produced fish with low and high condition, respectively, which was within the range found for wild Atlantic herring (Ma et al., 1998). In both instances the experimental temperatures were between 7 and $9^{\circ} \mathrm{C}$. Herring have also been successfully moved from a mixed diet of pellets and krill to a diet of only dry pellets (A. Thorsen, unpubl.data).

Energy, fat, protein, carbohydrate and vitamin content vary among food sources and may also alter during storage. The aquaculture industry supports a large and varied production of formulated dry pellets, most of which are sold with documentation on their nutritional content. In general, dry pellets made for salmon have a high fat content (20-30\%), while those used for marine fish such as Atlantic cod have a low fat content $(10-15 \%)$. When transferred to captivity, fish caught in the wild often refuse dry pellets and some individuals starve. However, Atlantic cod refusing dry pellets will usually resume feeding rapidly when offered capelin (Mallotus villosus), an important natural food source. Further alternatives to dry pellets for captive Atlantic cod include herring, squid and shrimp (Fordham and Trippel, 1999).

The choice and eventual mixing of different "natural" food items can mimic various environmental feeding conditions. In some cases where a mixture of different food items is to be used it may be helpful to homogenize the raw material in order to produce moist pellets. Technologically, wet pellet production is simple and can often be done on site. However, producing pellets usually implies grinding, which in turn may change the digestibility of the food. As well, the addition of flour for binding alters the nutritional content.

Austreng (1986) provides guidelines for the storage of wet and dry feed.

Wet feed (wet pellets or raw fish) is usually stored frozen. In general, lean fish may be stored about $50 \%$ longer than fat fish. At $-20^{\circ} \mathrm{C}$ fat fish may be stored for 3 months, while at $-30^{\circ} \mathrm{C}$ such fish may be stored for 6 months. If fish are "iced" they may be stored for twice the time. Degradation of vitamins and oxidation of unsaturated lipids limits the storage time of wet feed. Because of this, when fish are fed with frozen raw fish, the addition of vitamins is recommended, especially vitamin $\mathrm{C}, \mathrm{B}_{1}$ (thiamin) and $\mathrm{E}$. Adding vitamin $\mathrm{E}$ (lipid soluble anti oxidant) is important to reduce oxidation of lipids, especially in lipid rich food. Preparation of wet pellets may also require that the raw material be treated with high temperature $\left(>90^{\circ} \mathrm{C}\right)$ in order to denaturize the enzymes in fish that facilitate storage degradation (e.g. thiaminase that degrades vitamin $\mathrm{B}_{1}$ ).

Storing dry feed is usually easier since it can be stored for much longer (about a year) if frozen and well packed. If stored at room temperature $\left(\sim 20^{\circ} \mathrm{C}\right)$ the maximum recommended storage time is 3 months. Commercial dry feed usually contains vitamins that can be maintained within the specified levels providing the recommended storage time is adhered to.

Food competition among captive individuals often results in large differences in growth and condition, especially in cases where the amount of food is limited. In some experiments, such increased growth differences may be intended, but in other situations, large differences may be problematic. In the latter case, the problem may be solved by sorting fish with respect to body size or condition. Another way to reduce uneven growth among individuals under limited feeding regimes is to provide excess food during a single feeding period, but limit long-term consumption by periods of starvation (Karlsen et al., 1995).

In feeding experiments, an investigation may require knowledge of the amount of food ingested per individual. In some cases, when only a few fish are present in a tank, individual food consumption may be monitored by observation (Fordham and Trippel, 1999). When dealing with a large number of fish, the addition of small glass beads into food items has been used successfully (Kristiansen, 1998; Irwin et al., 2002). After feeding, the glass beads are counted using Xray detection, and food consumption estimated. However, fish normally have to be captured and handled, which unfortunately for some species might be difficult (e.g. Atlantic herring) without causing injuries or affecting subsequent behaviour in long-term feeding experiments.

\section{Tagging of Fish}

Tagging of fish is required in experiments where individual fish have to be monitored over time. Traditionally, external tags are attached near the anterior portion of the dorsal fin. Tags have been attached using a thin T-shaped plastic rod injected into the thick dorsal musculature or fastened through the base of the dorsal fin using thick monofilament. External tags are inexpensive and can be colour coded so that individuals held in small groups can be distinguished. Occasionally wounds occur and infections develop around a tag. Two tags per fish should always be used 
in case of tag loss and, when re-weighing fish, additional tags should be on hand to replace detached tags. In recent decades, internal pit tags have been increasingly used for fish tagging. A pit tag consists of a small glass cylinder (e.g. $3 \times 12 \mathrm{~mm}$ ) containing electronics, which are capable of responding with a unique tag number when energized by an external reader. These tags are usually placed under the skin, into the body cavity, or into the dorsal muscles and seldom cause any wound or infection. In addition, they are very durable (lasting at least the lifespan of the fish) and can be taken out and recycled after the fish is dead (Sandford and Smith, 2002).

\section{Monitoring Maturation}

In the prespawning period, it may be necessary to know the sex and maturity status of experimental fish. Ultrasonography (Karlsen and Holm, 1994) and/or biopsy through the oviduct (Bromly et al., 2000; Watanabe et al., 2001) are recommended. For female Atlantic cod, a biopsy needle consisting of a $10 \mathrm{~cm}$ long and $3 \mathrm{~mm}$ diameter glass tube connected to a 30 $\mathrm{cm}$ long silicone tube can be used. The edge of the glass tube should be rounded by the use of a burner flame so that it will not rupture the oviduct at insertion. The oviduct is located between the anus (anterior) and the urine papillae (posterior) (Morrison, 1990). Prior to the onset of spawning, the opening of the oviduct can be difficult to locate, especially in virgin fish, while during the spawning season it is more open and swollen. When the opening cannot be located, slight pressure with the biopsy needle will usually open it. However, the skin is rather thin in this area and the biopsy needle might rupture the skin of a male fish (which does not have an opening here) if too much force is applied. When collecting a biopsy the needle is carefully inserted $5-8 \mathrm{~cm}$ into the oviduct and the sample is taken by mouth suction.

In male fish, sperm are released through the urine papilla. During prespawning, it can sometimes be difficult to distinguish between sexes since the oviduct opening is very difficult to detect. In this situation, ultrasound is a good alternative to biopsy (Karlsen and Holm, 1994). Using ultrasound, maturing ovaries (bright) and testes (dark) can be distinguished and gonad size measured (Karlsen and Holm, 1994; MartinRobichaud and Rommens, 2001).

\section{Feeding During Spawning}

Temperate marine fish have often been observed to reduce or cease feeding during spawning. In paired mating studies, female and male Atlantic cod have been kept without food for 1.5-2 months (Fordham and
Trippel, 1999). Female Atlantic cod stop feeding 3 weeks prior to spawning and resume after $90 \%$ of their eggs have been released. Males reduce feeding even earlier and resume feeding once the paired female has completed spawning. The reduced appetite seems to be a result of the maturation and spawning process, since juveniles continue to feed and grow during the period when adults fast and spawn (Fordham and Trippel, 1999). During spawning, male and female cod lose between 10 and $50 \%$ of their mass depending on their initial condition (Kjesbu et al., 1991; Fordham and Trippel, 1999; Lambert and Dutil, 2000). Post-spawning appetite and meal sizes are very large, particularly among females. Feeding should be resumed soon after seasonal egg production is completed.

The mechanism responsible for reduced food ingestion during spawning is unclear, but also affects wild fish (Trippel et al., 1995; Link and Burnett, 2001). Perhaps it is related to the swollen state that females exhibit when eggs in the ovary become hydrated. This restricts the space in the body cavity and concurrently the volume of food that can be ingested. Other factors such as hormone levels also likely play a strong role in regulating appetite. On the other hand, observations have been made of Atlantic cod eating during the spawning period. Cod that enter spawning in a poor nutritional state, if presented with food, are capable of eating and maintaining a depressed level of egg batch production (albeit food consumption is low, E.A. Trippel, unpubl. data). Captive haddock also have been observed to ingest food during spawning (Hislop et al., 1978). Experiments have not been conducted to determine to what degree supplementary feeding during spawning influences in-season fecundity and egg quality. In the wild, fish commonly migrate to spawning areas and if these regions are sparse in prey, any additional nutritional requirements may not be able to be fulfilled, particularly in dense spawning shoals. Fish with insufficient energy stores may even elect not to spawn at all (Burton and Idler, 1987; Rideout et al., 2000). Stomach content analyses of Georges Bank cod and other species revealed some evidence of food in stomachs of fish in spawning condition, but the incidence was lower than of immature and post-spawning adults (Trippel et al., 1995; Link and Burnett, 2001).

Many researchers do not feed fish during spawning in order to eliminate unwanted food and fecal contamination in tanks and egg collectors. Microbial activity associated with contamination can affect incubation and development of eggs and embryos. If manual stripping is necessary, there is an additional risk that stripped eggs and sperm will be mixed with feces. Con- 
sequently, if eggs and embryos have to be incubated, it is recommended that fish not be fed during spawning.

\section{Spawning Conditions}

Production of high quality fertilized eggs is strongly dependent on the timing and course of the spawning act. In many batch-spawning fish with pelagic eggs successful spawning and fertilization are only obtained within a period of 5-10 hr after ovulation (Kjørsvik et al., 1990). Delayed spawning may result in a large fraction of overripe eggs (usually very large eggs) and low fertilization and survival rates. To achieve proper spawning, fish should be unstressed and have enough space to allow courtship behaviour. A stressed batch-spawning teleost, such as halibut (Hippoglossoides hippoglossoides) or cod, may not spawn at all or produce egg batches at irregular intervals with a high incidence of overripe and unfertilized eggs (Kjesbu, 1989) as well as abnormal larvae (Morgan et al., 1999). Stressed fish that do not spawn may still mature and ovulate eggs, but these eggs are kept within the ovarian lumen, which results in extreme expansion of the belly and often death (Fig. 1). Absence of sound production of male haddock in mated pairs could also serve to identify whether fish are stressed (Bremner et al., 2002).

Floating bags in the sea may be used to hold spawning fish, but land-based tanks are also common. At Austevoll Havbruksstasjon, spawning bags that are $6 \mathrm{~m}$ deep and $6 \mathrm{~m}$ in diameter have been successfully used for Atlantic cod (Holm and Andersen, 1990). Such bags are made for large groups of spawning fish (800$1000 \mathrm{~kg}$ ), but much smaller sizes have also been made for monitoring smaller groups or pairs. Usually the eggs in such spawning bags are collected with a specially designed egg collector at the water outlet (Fig. 2).

Using floating spawning bags in Norwegian fjords may have some special problems that require consideration. For floating bags, water commonly needs to be pumped from great depth to achieve stable quality with sufficient salinity for egg buoyancy. When using floating bags in a fjord system, where the surface water is relatively warm and of low salinity, the bags may become negatively buoyant (Holm and Andersen, 1990). Construction should therefore be solid and with sufficient floating capacity. The bag should also have several overflow outlets covered by plankton net. Should the bag rupture, it is suggested to have a net outside the bag to prevent fish from escaping (Holm and Andersen, 1990). To have efficient water renewal and egg collection on the water outlet the intake should be close to the bottom of the bag and horizontally di- rected $45^{\circ}$ to the bag's surface (Holm and Andersen, 1990). Advantages of spawning bags are their large volume capable of holding large numbers of adults and low construction cost.

The size of land-based spawning tanks may be a factor that limits successful spawning. An optimal tank shape that provides fish the possibility for continuous swimming (e.g. circular tanks) might compensate for small tank volumes. Egg collection might be more complicated in land-based tanks compared to floating spawning bags, where in the latter the collector may simply float in the water outside the bag (Fig. 2). If efficient egg collectors cannot be made for a tank, additional manual sampling directly in the tank with a plankton net can be a solution (Kjesbu, 1989; Buckley et al., 2000). Communal spawning in bags or tanks, however, does not permit the measurement of egg production of individual females. In these spawning systems, the investigator is unable to easily assess which fish are propagating during a spawning event and sometimes more than 2-3 egg batches may be spawned over a 24-hr period and mixed in the collector.

Small circular tanks with a flat bottom are recommended for paired mating studies (Fig. 3). A major advantage of circular over square tanks is better water circulation for fish husbandry and effective egg collection. Circular tanks also reduce the occurrence of injuries to fish caused by collisions in corners. Tanks should be large enough to permit courtship behaviour. Efficient egg production of 55-75 cm Atlantic cod has been observed in tanks of diameter, $1.8 \mathrm{~m}$ and depth, $0.8 \mathrm{~m}$ (volume, $2.1 \mathrm{~m}^{3}$ ) as well as in tanks of diameter, $1.8 \mathrm{~m}$, depth, $1.5 \mathrm{~m}$ (volume, $3.5 \mathrm{~m}^{3}$ ) (Trippel, 1998; Rakitin et al., 2001). Fish length in relation to tank diameter is important though tanks do not necessarily have to be deep (e.g. $0.8 \mathrm{~m}$ is sufficient). Small tanks with a water flow of 25 litre per min. allow a relatively good turnover rate and most eggs of a spawning event can be collected in less then $24 \mathrm{hr}$ (follows descending exponential curve). Fish should be exposed to natural photoperiod and dim light ( $<30$ lux). Females often reside near the water's surface while the males which are comparatively more active remain near the bottom (Hawkins and Amorim, 2000; Rakitin et al., 2001).

Placing two males with each female in a small spawning tank to create a spawning trio is not recommended, as the dual paternal effect complicates the male contribution to fertilization and hatching success (Trippel and Morgan, 1994 a, b; Rakitin et al., 1999; Trippel, 2003). Interestingly, the addition of a second male does not appear to improve fertilization success 


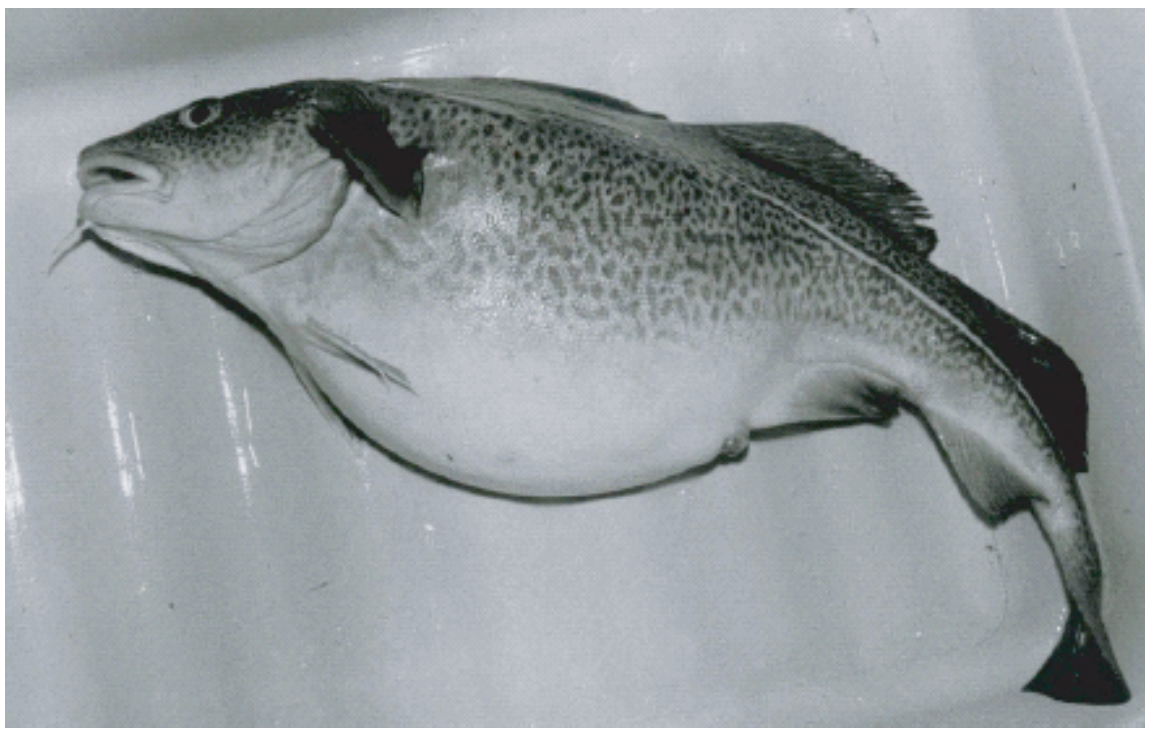

Fig. 1. Stressed females may retain several egg batches in their ovarian lumen and attain excessive belly size. This may in some cases cause death (Photo: O. S. Kjesbu).

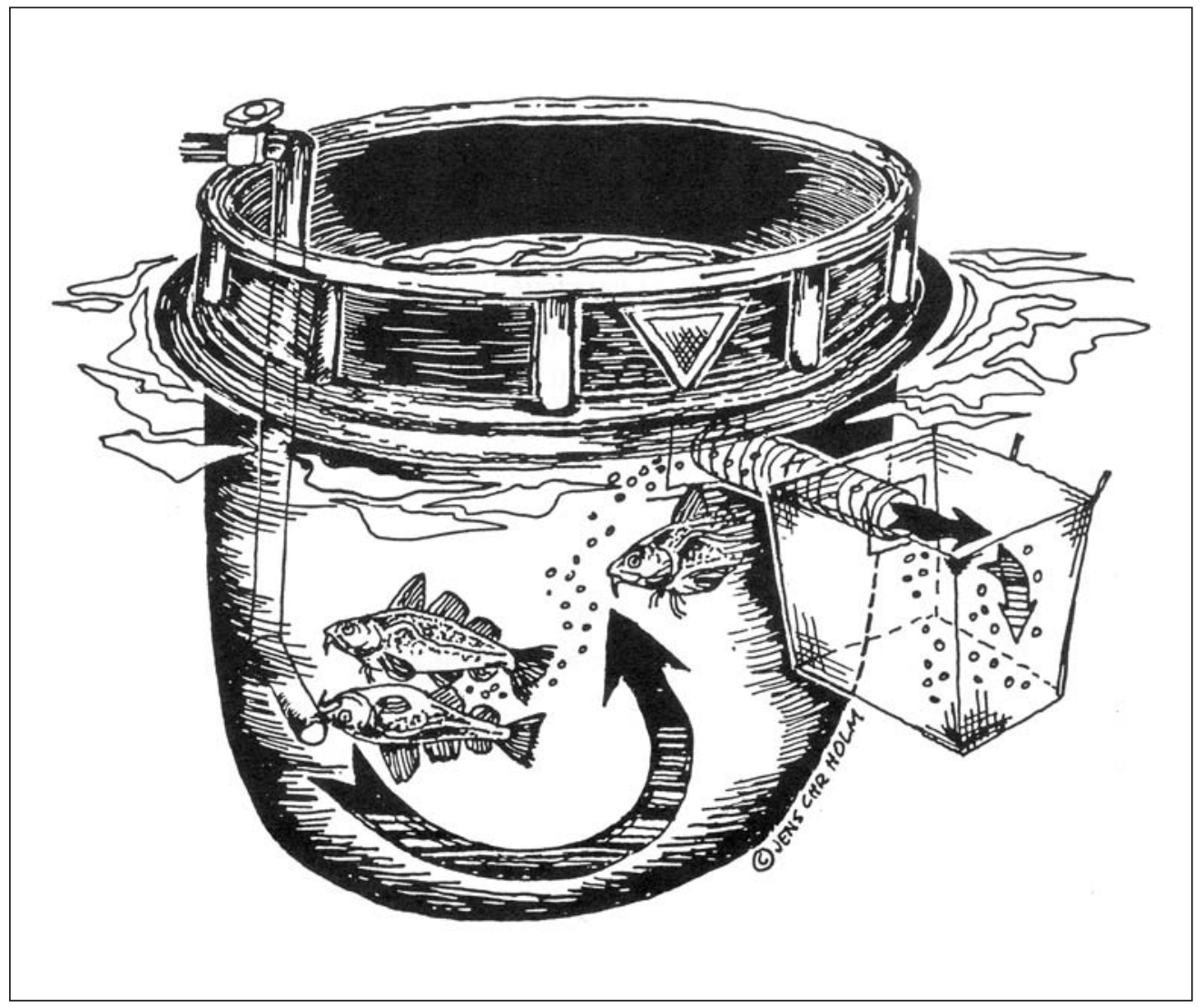

Fig. 2. Schematic representation of a floating spawning bag for cod with egg collector. Source: Holm and Andersen (1990). 
of Atlantic cod beyond that observed for spawning pairs (Rakitin et al., 2001). Mated trios of small North Sea haddock $(20-35 \mathrm{~cm})$ have been observed to successfully spawn in 3000 litre tanks (Hislop et al., 1978), though fertilization rates were not assessed.

Water temperature has been correlated with egg size in a number of studies (Miller et al., 1995; Chambers and Waiwood, 1996; Ouellet et al., 2001). Thus, choice of water temperature is an important aspect of egg production experiments and investigators should maintain water temperatures near those observed in the wild. It is likely that spawning temperature also influences the interval between batches as well as other spawning characteristics and egg quality.

\section{Egg Collection Techniques}

Egg collection devices commonly vary among institutions and individual designs are often adapted to on-site facilities and existing tank systems. When using floating spawning bags the plankton net that is used for egg collection (Fig. 2) should be rather large to prevent both clogging and physical damage to the eggs that can result from high water turbulence. Efficiency of egg collection in bags and tanks can be examined by inspecting the developmental stages of eggs that are found in the egg collector. If there are many eggs in advanced stages, the efficiency is low and adjustments should be made, i.e. increase the water supply.

For land-based tank systems, an egg collector device consisting of a 2-part system has been successfully deployed at the St. Andrews Biological Station for Atlantic cod and haddock (Trippel, 1998; Trippel et al., 1998, Fordham and Trippel, 1999; Rakitin et al., 2001). Egg collectors should be examined daily and eggs removed for subsequent processing. Two egg collectors are required per tank in order to estimate total fecundity, a surface collector for the floating fraction (live eggs) and a bottom drain collector for the sunken eggs (dead eggs) (Fig. 3). The surface collector can be fixed along the inside wall of a tank and the circular movement of water around the tank will move suspended eggs through the device (opening of egg collector $30 \times 30 \mathrm{~cm}$ in a $1.8 \mathrm{~m}$ diameter tank). A $1-\mathrm{mm}$ square mesh screen is used in surface egg collectors to filter eggs out of the water (egg diameter 1.3-1.6 $\mathrm{mm}$ ). Egg collectors should be examined daily and eggs removed for subsequent processing. These screens have to be cleaned occasionally to maintain good flow rates through the collector. Surface egg collectors can also be fitted to the outside of tanks and the out-flowing eggs entrapped while exiting though the surface outlet. The advantage of having an egg collector outside the tank is that it does not disturb the spawning fish. However, in outdoor winter conditions, these external egg collectors can experience sub-zero temperatures and they may be more appropriately used indoors or in combination with the use of a 'greenhouse' type shelter. Water depth filtered for suspended eggs is presumably greater for an internal versus external surface collector.

Typically, egg collectors collect only the floating portion of the eggs. Dead eggs and eggs with low buoyancy tend to sink to the bottom of the tank and are expelled through the drain. Eggs that settle to the tank bottom can be collected through drain collectors. A number of drain collector designs have been used. One involves the entrapment of eggs in a $1 \mathrm{~mm}$ square Nitex mesh 'sock' placed inside the external vertical drainpipe (Fig. 3). This drain egg collector is designed to be easily removed, eggs withdrawn and total volume recorded. Moreover, it is important, where possible, that the drain collector be constructed so that it does not collect live eggs, since eggs sucked into the drain are likely to be physically damaged when entrapped in the Nitex mesh 'sock'. At the St. Andrews Biological Station, eggs collected from the drain were high in ash content and unfertilized (Trippel et al., 2000; E. A. Trippel, unpubl. data). A flat tank bottom with a central bottom drain does not seriously impair collection of settled eggs and it also enables a uniform bottom surface for resting fish. Experience has shown that internal surface egg collectors should be fixed to the tank wall before fish are placed in the tank. If placed in after fish are introduced, some fish may consider the collector a threat and exhibit stress symptoms.

A problem using egg collectors is that they will also collect other particles from the water. If the eggs are kept in the egg collector for a long time, they will become covered with small particulate debris (depending on state of filtered water). During later incubation, this could lead to very high numbers of microorganisms on the eggs that could bloom and cause mass mortalities. It is therefore common to rinse such eggs in a disinfectant solution (e.g. Buffodine) before they are introduced to egg incubators.

\section{Spawning Fish and Stress}

In laboratory conditions, some fish will not spawn, spawn irregularly, or the spawned eggs will remain unfertilized. For Atlantic cod, a typical sign of stress is dark skin often accompanied by large pale spots. Stressed fish may also have long periods without swimming activity. In contrast, well-adapted spawning fish 

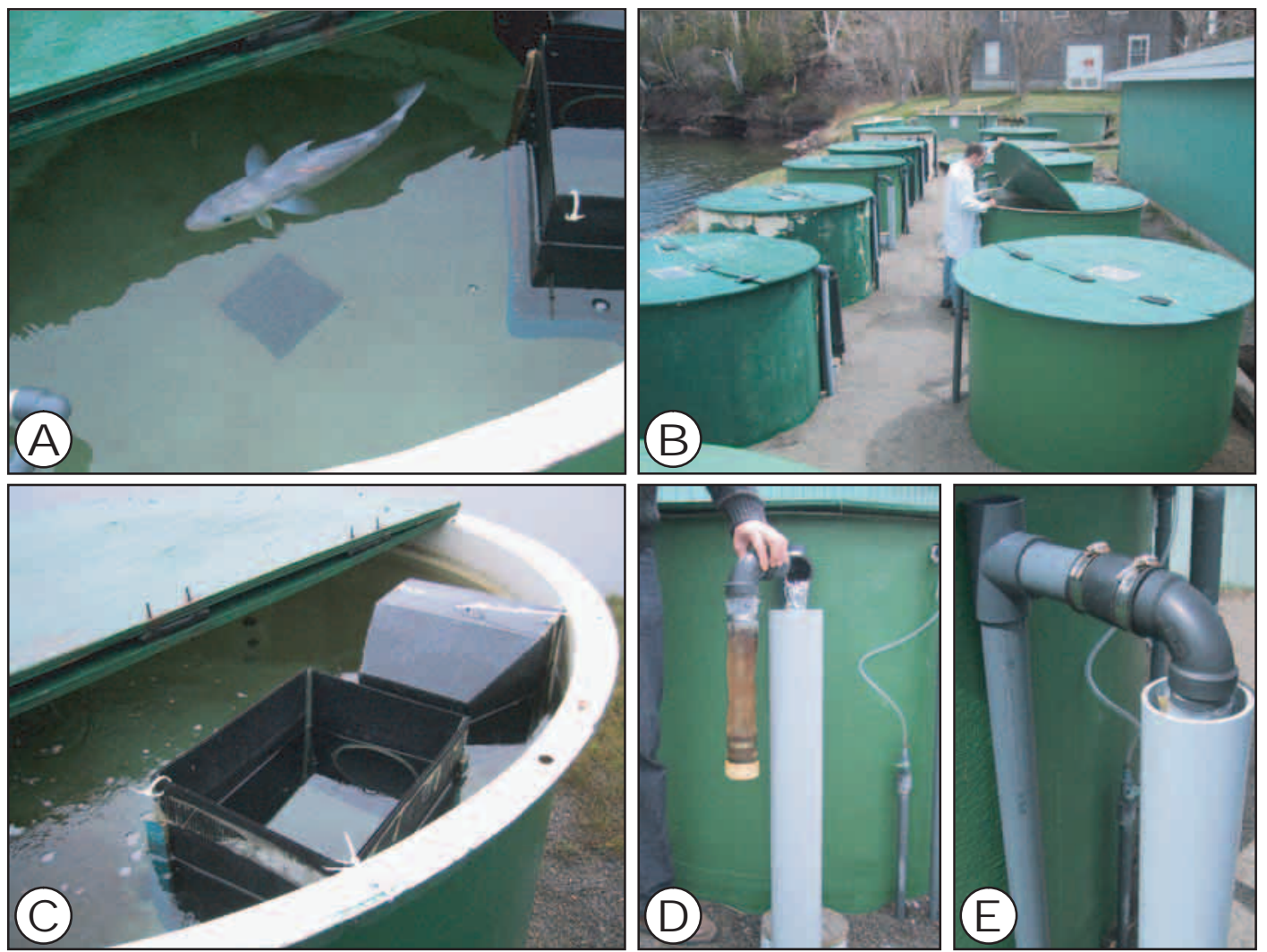

Fig. 3. Monitoring egg production of individual female gadoids may be conducted by maintaining adult pairs in small circular tanks (volume, $3.5 \mathrm{~m}^{3}$, diameter, $1.8 \mathrm{~m}$; and depth, $1.5 \mathrm{~m}$ ). (A) female haddock (length $45 \mathrm{~cm}$ ) near tank's surface; (B) ten outdoor tanks at the St. Andrews Biological Station used in paired mating studies; $(\mathbf{C})$ surface egg collector attached to side of tank, eggs are collected from the open portion using a small fine-mesh dip net; (D-E) eggs passing through the bottom drain are collected in the outlet using a 1-mm mesh "sock" that can be detached from the stand-up drain pipe and eggs subsequently removed by unscrewing the white threaded bottom cap. (Photos: E. A. Trippel and R. M. Rideout).

often swim slowly, with males often exhibiting precourtship behaviour (Hawkins and Amorim, 2000). In some situations, substitution of fish is required to induce adequate spawning performance.

In captivity, some species are more prone to stress than others. Atlantic cod is an excellent species with which to conduct egg production experiments. They spawn naturally in captivity and can be stripped and weighed a number of times during a spawning season. Females are more sensitive to handling than males due to the enlarged ovary, thin ovarian membrane, and sensitivity of eggs relative to sperm. Haddock are more susceptible to handling stress than Atlantic cod. The thin mucous layer of haddock is easily removed, descaling occurs, and the caudal fin ray membranes become shredded if fish are handled once every three weeks using dip nets (E. A. Trippel, personal observa- tions). Surface egg collectors in tanks with haddock require high-density foam padding glued to their hard edges to reduce skin and fin abrasions. Handling of adult haddock should be very gentle using a fine-nylon dip net with several $3 \mathrm{~cm}$ holes to allow water to pass through for draining. Flatfishes have coarse skin and are tolerant of successive handling. When externally tagged fish of any species are netted, the investigator must be careful that the plastic anchor tags do not become entangled in the dip net's mesh and become withdrawn from the animal as it struggles.

Fish occasionally die during spawning, and this usually occurs near the end of spawning or shortly after spawning is completed. Post-spawning mortality seems to occur more often among males than females, whereas during spawning some females become 'plugged' and die. 


\section{Artificial Fertilization}

Stripping eggs for artificial fertilization is often difficult to achieve, as the eggs may have only a few hours after ovulation before they must be spawned and fertilized. Fertilization frequency and quality of stripped eggs may therefore be variable and inferior to eggs from natural spawning. Nevertheless, some species such as Atlantic halibut and other flatfish will usually not spawn in tanks and stripping is the only alternative (Litvak, 1999). In these cases, it is best to follow the ovulation cycle for each female and to strip each within a few hours after ovulation (Norberg et al., 1991).

Some species that produce demersal eggs ovulate and spawn all their eggs in one batch (e.g. winter flounder, Pseudopleuronectes americanus). Often the eggs from such species can be stored in the ovarian lumen for several days or even weeks before they are spawned without degradation of egg quality (Kjørsvik et al., 1990). In many such cases the realized fecundity can be found by stripping or slaughtering females that contain ovulated eggs.

In some species, ovulation will not take place spontaneously in captivity or ovulation is difficult to time. In such cases, hormonal injection (e.g. human chorionic gonadotropin) may be used to trigger final maturation and ovulation (Moriwaki et al., 1991, Suresh et $a l ., 2000)$. However, hormonal stimulation may cause several batches to mature more or less at the same time causing severe expansion of the ovary. Details on how to artificially fertilize eggs are reported by Trippel (2003).

\section{Initial Egg Sample Analysis}

Two principal characteristics are measured after egg collection; total egg volume and egg diameter. When total volume of an egg batch and the average diameter of $20-60$ eggs have been measured the batch's fecundity can be estimated using a calibrated packing density equation (Kjesbu, 1989).

Normally, egg diameter is strongly correlated with egg dry weight (Thorsen et al., 1996), and thus diameter might be a good descriptor of egg size. However, environmental adaptations may cause eggs of different stock origin to have very different relations between diameter and dry weight. This can be seen when comparing eggs from marine and brackish water environments. Increased water content is the main buoyancy adaptation for cod and flatfish eggs in brackish water (Solemdal, 1973; Thorsen et al., 1996). Brackish water cod eggs from the Baltic Sea typically have an absolute water content which is twice as large as that found for marine cod eggs of similar dry weight (Thorsen et al., 1996), and therefore the two egg types also have completely different dry weight-diameter relations. Egg dry weight (and sometimes egg energy) is often used instead of, or in addition to, egg diameter as a measure of size or quality.

When measuring egg dry weight, it is important to be aware of the amount of seawater salts that are present in the perivitelline space (PVS). The PVS is created when the egg is activated after spawning and consists mainly of seawater and a small amount of protein macromolecules with a size of about $9 \mathrm{kD}$ (Inoue and Inoue, 1986). In an Atlantic cod egg (which is probably typical for a marine pelagic teleost egg) about $20 \%$ of the total egg volume is PVS (Mangor-Jensen, 1987 ) and the amount of PVS seawater salts is about $10 \%$ of total egg dry weight. The chorion of fish eggs is very porous for small molecules such as water and salts. Thus, the seawater salts present in the PVS can be washed out by rinsing the eggs in distilled water. Experiments on Atlantic cod eggs have shown that it takes about one minute to wash out the PVS salts (Mangor-Jensen, 1987). If eggs are rinsed with distilled water for only a short time, e.g. $10 \mathrm{sec}$, the rinsing will be incomplete. Consequently, when using a short rinsing time only minor variations in rinse time will cause variation in the resulting dry weight. Therefore, one should choose to either rinse the eggs for at least one minute, or not to rinse them at all. The vitelline membrane, which surrounds the yolk, is very impermeable after activation (fertilization) and can tolerate several minutes of washing in distilled water without losing significant amounts of solutes (Mangor-Jensen, 1987).

Other egg quality descriptors that are commonly used on newly spawned eggs are fertilization rate, fraction of live eggs, floating fraction, and abnormal cell division. Among the unfertilized eggs, there are two types (Fig. 4); those that are inactivated (without blastodisc and PVS) and those that are activated (have PVS and blastodisc). Strangely, a small fraction of the unfertilized eggs that are activated may show one or two cell divisions before development stops. This has been observed of stripped Atlantic cod eggs to which sperm were not added (A. Thorsen, unpubl. data).

The percentage of eggs with irregular cell divisions (Fig. 5) has been used to describe egg quality in many fish species (Kjørsvik et al., 1990). However, recent research shows that eggs with irregular initial cell divisions may develop into normal embryos (Shields et al., 1997; Vallin and Nissling, 1998). 


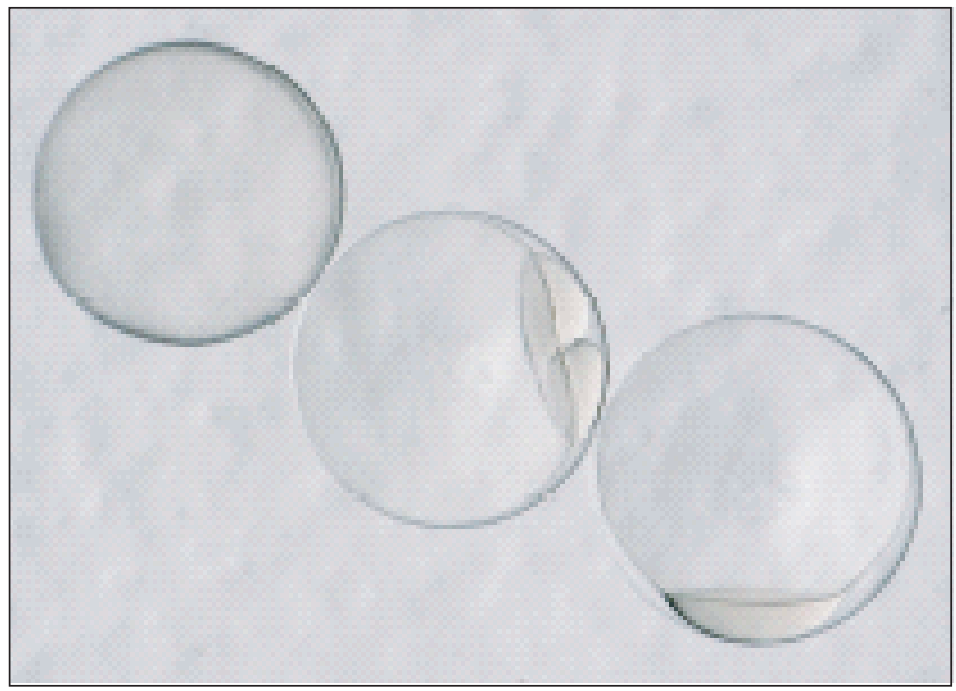

Fig. 4. Unfertilized and newly fertilized eggs of cod. Left, an unfertilized inactivated egg; Middle, a fertilized egg in the two cell (blastomere) stage; Right, an unfertilized activated egg (note no cell division).
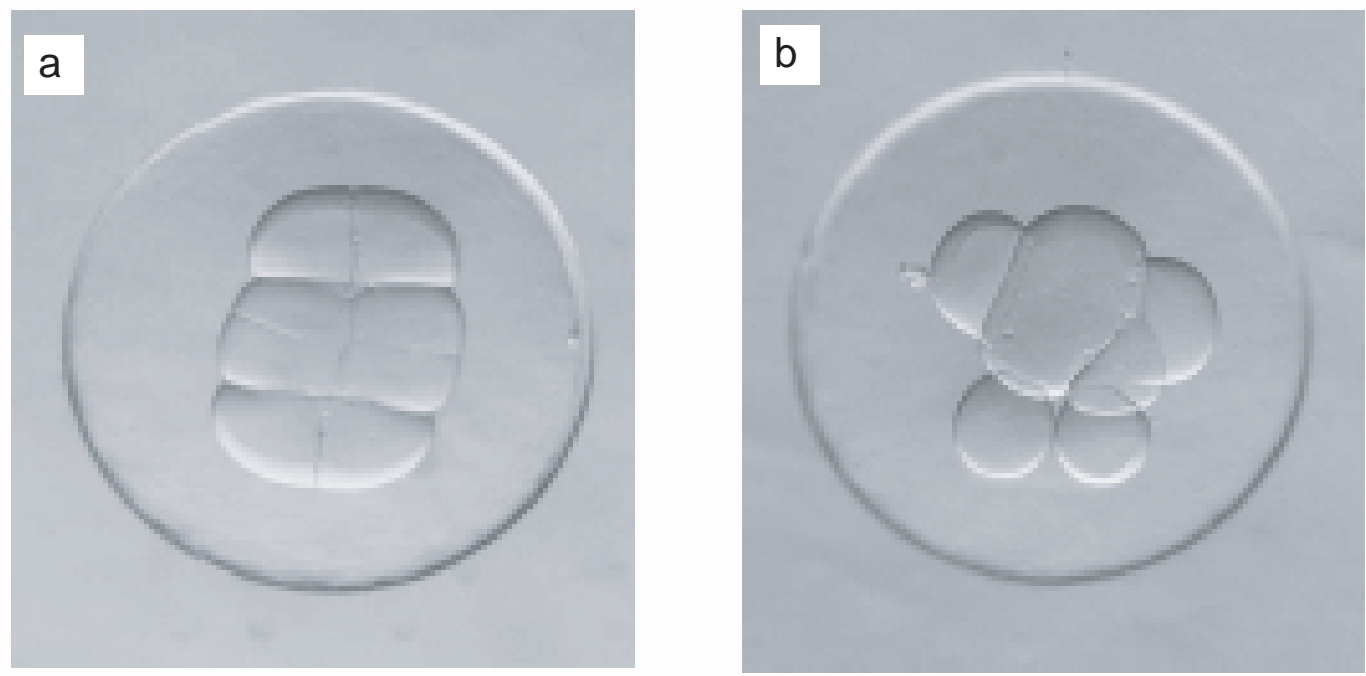

Fig. 5. Regular (a) and irregular (b) cell cleavage. Both cod eggs developed into yolk sac larvae of normal appearance (A. Thorsen, unpubl. data).

\section{Egg and Larval Quality and Mortality}

Egg quality is also evaluated by incubating eggs and measuring hatching rate, time to yolk sac absorption and/or larval size, growth, and viability until metamorphosis. Two principally different methods have been used for testing embryo and larval viability. In the first, a known number of embryos (usually hundreds or thousands) are maintained in incubators containing up to several liters of water. Water in the incu- bators may be flow through or static. In the latter situation, the water is usually replaced every $1-2$ days and antibiotics and fungicides added. When an egg dies, its nutrients are released due to leakage, and become available for micro-organisms. If enough eggs die the nutrient loss can contribute to a bloom of microorganisms that may infect the entire egg batch (A. Thorsen, unpubl. data). The chance of epidemic infections increases as the number of eggs in the incubator increases, especially in incubators with static water. Such 
incubations, therefore, have to be done using several replicates and the incubators should be inspected daily, dead eggs removed, and water exchanged frequently.

As an alternative, a method has evolved that is based on the incubation of single eggs in small cell culture wells (Solemdal et al., MS 1998; Vallin and Nissling, 1998; Panini et al., 2001). This has been performed using Nunc-cell culture multidishes that contain 24 wells of $3 \mathrm{ml}$ each. The wells are filled with $2 \mathrm{ml}$ of autoclaved $70 \%$ seawater, and eggs are added individually using a Pasteur pipette. The multidish is then placed in a controlled temperature room and inspected with a binocular microscope for developmental stage, mortality, abnormalities and hatching. Forty-eight eggs are usually incubated per egg batch. No water renewal is necessary during the egg and yolk sac stage. Using diluted seawater ( $70 \%$ strength) as the incubation medium in single egg incubations serves two purposes. Autoclaving full-strength seawater causes precipitation of salts, which does not occur in $70 \%$ seawater. Atlantic cod eggs are not buoyant at this salinity and settle to the bottom, thereby easing the process of conducting inspections using a binocular microscope.

In comparison with incubation of groups of eggs, the single egg incubation method is often less laborious, and the equipment needed is inexpensive. Most important, death of some eggs does not cause infection of others. In addition, the method is simple enough that it can be carried out in the field and on research cruises. However, the low number of eggs used for this kind of incubation offers very limited possibilities for sampling of eggs or larvae for other purposes, such as biochemical analyses. As well, the number of larvae produced will normally be too small for subsequent experimental use (e.g. feeding and growth trials).

In order to establish patterns of mortality during incubation in either individual or group egg lots, it is advisable to record the incidence of dead embryos daily. Dead and living embryos could be periodically viewed to determine the embryonic stage of development. Near the end of incubation, when advanced embryos approach hatching, the egg's chorion may partially open. Larvae may leave the egg at this stage or they may remain in the egg for some time while the burst egg loses its buoyancy and sinks to the bottom of the incubator (i.e. in full-strength sea water). These sinking embryos may (i) still successfully hatch and be viable larvae, (ii) die before hatching, or (iii) hatch but remain on the bottom and eventually die. One should be careful not to remove these eggs prema- turely and consider them dead, particularly if they fall into (i) above. If they are removed, they should be placed into separate incubators for monitoring. It may take 3-4 days for all viable eggs of a sample to hatch.

Starvation time can also be examined in relation to parental origin. Viable larvae (Day 0) can be removed and incubated in groups ( 5 replicates of $\sim 25-50$ larvae in $100 \mathrm{ml}$ beakers) or individually in cell-culture multidishes (48 replicates). Dead larvae are easily identified by their bent and shriveled state and should be enumerated and removed daily. Larval viability can be further verified under a stereomicroscope by the presence of a heart beat. Time to $100 \%$ mortality is often 15-20 days post-hatch depending on species and temperature. Time to $50 \%$ mortality can be estimated from daily mortalities.

Larval characteristics are often measured at hatch and at the middle and/or end of the yolk-sac phase. For cod held at $5^{\circ} \mathrm{C}$ this corresponds to about 3 and 7 days posthach. A small well slide or watch glass is ideal for holding anesthetized larvae while high resolution images are captured using a digital camera or video recorder. The large fin folds often permit an individual larva to remain partially erect but the lowering of the water level situates a larva on its side with only one eye visible. This posture assists in obtaining high precision in larval trait measurements. Common measurements include standard length, yolk sac area, eye diameter, myomere depth, and features of the head (fin fold area is also possible) (Hunt von Herbing, 2001). Yolk sac area can be estimated by tracing the area on the monitor using appropriate computer software. Measurement of yolk sac size over several days can provide an estimate of rate of depletion of yolk reserves.

Additional larvae can be frozen (liquid nitrogen, or $\left.-80^{\circ} \mathrm{C}\right)$ or preserved $(95 \%$ ethanol or $4 \%$ buffered formaldehyde) for subsequent analyses. Dry larval weight can be obtained from either of these stored samples, but preferably from $95 \%$ ethanol. Freezing can burst the yolk sac and formaldehyde is associated with changes in length and weight, the direction and magnitude of which appears to be partly linked to larval size and species (Pepin et al., 1998). However, from a scalar perspective, data will presumably be pertinent if samples are analyzed over a short period after preservative effects have stabilized (usually several months). For formaldehyde-preserved larvae, the yolk sac can be dissected from a larva's body and the two parts separately dried to obtain values of yolk as a percent 
of total larval dry weight (Peterson et al., 1996; Trippel, 1998). Acetic acid (diluted) followed by rinsing in distilled water can be used to rapidly remove any formaldehyde buffer residue that may have developed on larvae during storage. Ethanol stored samples can be used for analyses of percent ash and lipid content and fatty acid composition (e.g. Picovka et al., 1997; Trippel et al., 2000).

The evaluation of offspring quality during larval feeding is usually very laborious and complicated, since the typical marine fish larval demands live food and large incubation tanks. Due to the complexity of such systems there is often a so-called "tank effect" that may have a large influence on results, hence it is commonly recommended to conduct several replicate incubations. As an alternative to large tanks, the use of small 30-litre glass aquaria as experimental larval rearing units have been successfully used for advanced rearing of cod larvae until 6 weeks post hatch (Puvanendran and Brown, 1999).

The evaluation of offspring quality in some cases has been performed by pooling all the larvae into only one or two large tanks. Surviving offspring have then been linked to parent fish using DNA fingerprinting techniques (Blom et al., 1994; Svåsand et al., MS 2000). This technique allows the "tank effect" to be neutralized, and the work needed for incubation and feeding experiments can be reduced to acceptable levels. Even though DNA fingerprinting techniques have been developed in recent years, these analyses are still expensive and complicated. However, the increased range of possibilities in experimental design seems to justify their use in many cases. Development of less expensive and simpler DNA fingerprinting techniques would probably stimulate many new experiments on the effects of parental characteristics on progeny quality and performance.

\section{Acknowledgements}

The authors greatly appreciate the comments and advice given by two referees towards the improvement of an earlier draft of the manuscript. Financial support was provided by the Research Council of Norway (No. 133836/122) and the European Commission (Contract No. FAIR-CT-98-4122, STEREO) (to A. Thorsen).

\section{References}

ARMSTRONG, M., P. CONNOLLY, R. NASH, M. PAWSON, E. ALESWORTH, P. COULAHAN, M. DICKEY-COLLAS, S. MILLIGAN, M. O'NEILL,
P. WITTHAMES, and L. WOOLNER. 2001. An application of the annual egg production method to estimate the spawning biomass of cod (Gadus morhua L.), plaice (Pleuronectes platessa L.) and sole (Solea solea L.) in the Irish Sea. ICES J. Mar. Sci., 58: 183203.

AUSTRENG, E. 1986. Fóring av laksefisk. In: Fiskeoppdrett med framtid. T. Gjedrem (ed.). A/S Landbruksforlaget, Oslo, p. 164-199.

BERGSTAD, O., T. JØRGENSEN, and O. DRAGESUND. 1987. Life-history and ecology of the gadoid resources of the Barents sea. Fish. Res., 5: 119-161.

BISHOP, M., and S. GREEN. 2001. Predation on Pacific herring (Clupea pallasi) spawn by birds in Prince William Sound, Alaska. Fish. Oceanogr., 10: 149-158.

BLOM, G., T. SVÅSAND, K. E. JØRSTAD, H. OTTERÅ, O. I. PAULSEN, and J. C. HOLM. 1994. Comparative survival and growth of two strains of Atlantic cod (Gadus morhua) through the early life stages in a marine pond. Can. J. Fish. Aquat. Sci., 51: 1-14.

BREMNER, A. A., E. A. TRIPPEL, and J. M. TERHUNE. 2002. Sound production by adult haddock, Melanogrammus aeglefinus, in isolation, pairs and trios. Environ. Biol. Fish., 65: 359-362.

BROMLEY, P. J., C. RAVIER, and P. R. WITTHAMES. 2000. The influence of feeding regime on sexual maturation, fecundity and atresia in first-time spawning turbot. J. Fish Biol., 56: 264-278.

BUCKLEY, L. J., T. M. BRADLEY, and J. ALLENGUILMETTE. 2000. Production, quality, and low temperature incubation of eggs of Atlantic cod Gadus morhua and haddock Melanogrammus aeglefinus in captivity. J. World Aqua. Soc., 31: 22-29.

BURTON M. P., and D. R. IDLER. 1987. An experimental investigation of the nonreproductive, post-mature state in winter flounder. J. Fish Biol., 30: 643-650.

CARDINALE, M., and F. ARRHENIUS. 2000. Decreasing weight-at-age of Atlantic herring (Clupea harengus) from the Baltic Sea between 1986 and 1996: A statistical analysis. ICES J. Mar. Sci., 57: 882-893.

CHAMBERS, R. C., and K. G. WAIWOOD. 1996. Maternal and seasonal differences in egg sizes and spawning characteristics of captive Atlantic cod, Gadus morhua. Can. J. Fish. Aquat. Sci., 53: 1986-2003.

DUTIL, J. D., J. MUNRO, C. AUDET, and M. BESNER. 1992. Seasonal variation in the physiological response of Atlantic cod (Gadus morhua) to low salinity. Can. J. Fish. Aquat. Sci., 49: 1149-1156.

FORDHAM, S. E., and E. A. TRIPPEL. 1999. Feeding behaviour of cod (Gadus morhua) in relation to spawning. J. Appl. Ichthyol., 15: 1-9.

FRIDGEIRSSON, E. 1978. Embryonic development of five species of gadoid fishes in Icelandic waters. Rit Fiskideildar, 5: 1-68.

GISBERT, E., P. WILLIOT, and F. CASTELLO-ORVAY. 2000. Influence of egg size on growth and survival of early stages of Siberian sturgeon (Acipenser baeri) under small scale hatchery conditions. Aquaculture, 183: 83-94. 
HARDARDOTTIR, K. MS 2001. Relationship between atresia, fish size and condition in Icelandic cod (Gadus morhua L.). Cand. Scient thesis, University of Bergen, Norway.

HAWKINS, A., and M. AMORIM. 2000. Spawning sounds of the male haddock, Melanogrammus aeglefinus. Environ. Biol. Fish., 59: 29-41.

HISLOP, J. R. G., A. P. SCOTT, and J. A. GAULD. 1978. Observations on the effects of feeding level on growth and reproduction in haddock, Melanogrammus aeglefinus (L.), in captivity. J. Fish Biol., 13: 85-98.

HJORT, J. 1914. Vekslingerne i de store fiskerier, H. Aschehoug and Co. (W. Nygaard), Kristiania, Norway, $266 \mathrm{p}$.

HOLM, J., and E. ANDERSEN. 1990. Produksjon av egg og larver. In: Håndbok i Torskeoppdrett; Stamfiskhold og Yngelproduksjon. J. C. Holm, T. Svåsand, and V. Wennevik (eds.). Havforskningsinstituttet, Senter for Havbruk, Bergen, Norway, p. 29-42.

HOLST, J. C. MS 1996. Long term trends in the growth and recruitment pattern of the Norwegian spring-spawning herring (Clupea harengus Linnaeus 1758). Dr. Scient thesis, Department of Fisheries and Marine Biology, University of Bergen, Norway.

HUNT, VON HERBING, I. 2001. Development of feeding structures in larval fish with different life histories: winter flounder and Atlantic cod. J. Fish Biol., 59: $767-782$.

INOUE, S., and Y. INOUE. 1986. Fertilization (activation)induced 200-to 9-kDa depolymerization of polysialoglycoprotein, a distinct component of cortical alveoli of rainbow trout eggs. J. Biol. Chem., 261: 5256-5261.

IRWIN, S., J. O'HALLORAN, and R. FITZGERALD. 2002. The relationship between individual consumption and growth in juvenile turbot, Scophthalmus maximus. Aquaculture, 204: 65-74.

JÓNSSON, B., and E. SVAVARSSON. 2000. Connection between egg size and early mortality in Arctic charr, Salvelinus alpinus. Aquaculture, 187: 315-317.

KARLSEN, Ø., and J. C. HOLM. 1994. Ultrasonography, a non-invasive method for sex determination in cod (Gadus morhua). J. Fish Biol., 44: 965-971.

KARLSEN, Ø., J. C. HOLM, and O. S. KJESBU. 1995. Effects of periodic starvation on reproductive investment in first-time spawning Atlantic cod (Gadus morhua L.). Aquaculture, 133: 159-170.

KARLSEN, Ø., G. TARANGER, R. DAHLE, and B. NORBERG. 1999. Effects of exercise and continuous light on early sexual maturation in farmed Atlantic cod (Gadus morhua L.). In: Procedings of the 6th international symposium on the reproductive physiology of fish. B. Norberg, O. S. Kjesbu, G. L. Taranger, E. Andersson, and S. O. Steffansson (eds.). Institute of Marine Research and University of Bergen, 4-9 July 1999, p. 328-330.

KJESBU, O. S. 1989. The spawning activity of cod, Gadus morhua L. J. Fish Biol., 34: 195-206.

KJESBU, O. S., and J. C. HOLM. 1994. Oocyte recruitment in first-time spawning Atlantic cod (Gadus morhua) in relation to feeding regime. Can. J. Fish. Aquat. Sci., 51: 1893-1898.

KJESBU, O. S., J. KLUNGSØYR, H. KRYVI, P. R. WITTHAMES, and M. GREER WALKER. 1991. Fecundity, atresia, and egg size of captive Atlantic cod (Gadus morhua) in relation to proximate body composition. Can. J. Fish. Aquat. Sci., 48: 2333-2343.

KJESBU, O. S., P. R WITTHAMES, P. SOLEMDAL, and M. WALKER. 1998. Temporal variations in the fecundity of Arcto-Norwegian cod (Gadus morhua) in response to natural changes in food and temperature. J. Sea Res., 40: 303-321.

KJØRSVIK, E., and S. LØNNING. 1983. Effects of egg quality on normal fertilisation and early development of cod, Gadus morhua L. J. Fish Biol., 23: 1-12.

KJØRSVIK, E., A. MANGOR-JENSEN, and I. HOLMEFJORD. 1990. Egg quality in fishes. Adv. Mar. Biol., 26: 71-113.

KNUTSEN, G. M., and S. TILSETH. 1985. Growth, development, and feeding success of Atlantic cod larvae Gadus morhua related to egg size. Trans. Am. Fish. Soc., 114: 507-511.

KRISTIANSEN, H. 1998. Effects of handling, discrete meals and body weight on the individual variation of gastric emptying parameters. Aquacult. Res., 29: 717-729.

KURITA, Y., A. THORSEN, M. FONN, A. SVARDAL, and O. S KJESBU. 1999. Oocyte growth and fecundity regulation of Atlantic herring (Clupea harengus) in relation to declining body reserves during overwintering. In: Proceedings of the 6th international symposium on the reproductive physiology of fish. B. Norberg, O. S. Kjesbu, G. L. Taranger, E. Andersson, and S. O. Steffansson (eds.). Institute of Marine Research and University of Bergen, 4-9 July 1999, p. 85-87.

LAMBERT, Y., and J.-D. DUTIL. 2000. Energetic consequences of reproduction in Atlantic cod (Gadus morhua) in relation to spawning level of somatic energy reserves. Can. J. Fish. Aquat. Sci., 57: 815-825.

LEKANG O. D., and S. O. FJÆRA. 1997. Teknologi for Akvakultur. Landbruksforlaget, Otta, Norway, 419 p.

LINK, J., and J. BURNETT. 2001. The relationship between stomach contents and maturity state for major northwest Atlantic fishes: new paradigms? J. Fish Biol., 59: 783-794.

LITVAK, M. K. 1999. The development of winter flounder (Pleuronectes americanus) in Atlantic Canada: current status and future prospects. Aquaculture, 176: 55-64.

LLORET, J., and H. RÄTZ. 2000. Condition of cod (Gadus morhua) off Greenland during 1982-1998. Fish. Res., 48: 79-86.

MA, Y., O. S. KJESBU, and T. JØRGENSEN. 1998. Effects of ration on the maturation and fecundity in captive Atlantic herring (Clupea harengus). Can. J. Fish. Aquat. Sci., 55: 900-908.

MAKHOTIN, V., P. SOLEMDAL, K. KORSBREKKE, and A. SALTHAUG. MS 2001. Types and frequency of malformations and mortality in eggs of Arcto-Norwegian cod: A field study. ICES C.M. Doc., No. 2001/N:12.

MANGOR-JENSEN, A. 1987. Water balance in developing 
eggs of the cod Gadus morhua L. Fish Physiol. Biochem., 3: $17-24$.

MARSHALL, C. T., O. S. KJESBU, N. A. YARAGINA, P. SOLEMDAL, and Ø. ULLTANG. 1998. Is spawner biomass a sensitive measure of the reproductive and recruitment potential of Northeast Arctic cod? Can. J. Fish. Aquat. Sci., 55: 1766-1783.

MARTIN-ROBICHAUD, D. J., and M. ROMMENS. 2001. Assessment of sex and evaluation of ovarian maturation of fish using ultrasonography. Aquacult. Res., 32: $113-120$.

MATTSON, N. S., and T. H. RIPLE. 1989. Metomidate, a better anesthetic for cod (Gadus morhua) in comparison with benzocaine, MS-222, chlorobutanol, and phenoxyethanol. Aquaculture, 83: 89-94.

MCEVOY, L. A., and J. MCEVOY. 1991. Size fluctuation in the eggs and newly hatched larvae of captive turbot (Scopthalmus maximus). J. Mar. Biol. Assoc., U.K., 71: 679-690.

MEEKAN, M. G., and L. FORTIER. 1996. Selection for fast growth during the larval life of Atlantic cod Gadus morhua on the Scotian Shelf. Mar. Ecol. Prog. Ser., 137: 25-37.

MELLE, W. 1985. Predasjon på torskens egg og larver i Lofoten. Houdfagsoppgåve i Fiskeribiologi, Institutt for Fiskeribiologi, Universitetet i Bergen, Norway.

MIDDAUGH, D., B. ANDERSON, and M. HEMMER. 1992. Laboratory spawning of topsmelt, Atherinopsaffinis, with notes on culture and growth of larvae. Environ. Toxicol. Chem., 11: 393-399.

MILLER, T. J., T. HERRA, and W. C. LEGGETT. 1995. An individual-based analysis of the variability of eggs and their newly hatched larvae of Atlantic cod (Gadus morhua) on the Scotian shelf. Can. J. Fish. Aquat. Sci., 52: 1083-1093.

MORGAN, M. J., C. E. WILSON, and L. W. CRIM. 1999. The effect of stress on reproduction in Atlantic cod. J. Fish Biol., 54: 477-488.

MORIWAKI, T., M. KOBAYASHI, K. AIDA, and I. HANYU. 1991. Changes in plasma gonadotropin and steroid-hormone levels during ovulation induced by hcg treatment in female goldfish. Nipp. Suis. Gakk., 57: 41-43.

MORRISON, C. M. 1990. Histology of the Atlantic cod, Gadus morhua: An atlas, Part three. Reproductive tract. Can. Spec. Publ. Fish. Aquat. Sci., 110: 177 p.

MURUA, H., and F. SABORIDO-REY. 2003. Female reproductive strategies of marine fish species and their classification in the North Atlantic. J. Northw. Atl. Fish. Sci., 33: 23-31 (this volume).

NORBERG, B., V. VALKNER, J. HUSE, I. KARLSEN, and G. LEROEY GRUNG. 1991. Ovulatory rhythms and egg viability in the Atlantic halibut (Hippoglossus hippoglossus). Aquaculture, 97: 365-371.

OUELLET, P., Y. LAMBERT, and I. BÉRUBÉ. 2001. Cod egg characteristics and viability in relation to low temperature and maternal nutritional condition. ICES J. Mar. Sci., 58: 672-686.

PANINI, E. B., C. L. MYLONAS, S. ZANUY, M. CARRILLO, J. RAMOS, and M. P. BRUCE. 2001.
Incubation of embryos and larvae of marine fish using microtiter plates. Aquacult. Inter., 9(2): 189-195.

PEPIN, P., J. F. DOWER, and W. C. LEGGET. 1998. Changes in the distribution of larval fish body length following preservation. Fish. Bull. U.S., 96: 633-640.

PETERSON, R. H., D. J. MARTIN-ROBICHAUD, and Å. BERGE. 1996. Influence of temperature and salinity on length and yolk utilization of striped bass larvae. Aquacul. Internat., 4: 89-103.

PICKOVA, J., P. C. DUTTA, P. O. LARSSON, and A. KIESSLING. 1997. Early embryonic cleavage pattern, hatching success, and egg-lipid fatty acid composition: comparison between cod (Gadus morhua) stocks. Can. J. Fish. Aquat. Sci., 54: 2410-2416.

PUVANENDRAN, V., and J. A. BROWN. 1999. Foraging, growth and survival of Atlantic cod larvae reared in different prey conditions. Aquaculture, 175: 77-92.

RAKITIN, A., M. M., FERGUSON, and E. A. TRIPPEL. 1999. Sperm competition and fertilization success in Atlantic cod: effect of sire size and condition factor on gamete quality. Can. J. Fish. Aquat. Sci., 56: 2315-2323.

RAKITIN, A., M. M., FERGUSON, and E. A. TRIPPEL. 2001. Male reproductive success and body size in Atlantic cod Gadus morhua L. Mar. Biol., 138: 1077-1085.

RIDEOUT R. M., M. P. M. BURTON, and G. A. ROSE. 2000. Observations on mass atresia and skipped spawning in northern Atlantic cod, from Smith Sound, Newfoundland. J. Fish Biol., 57: 1429-1440.

ROTHSCHILD, B. J. 1986. Dynamics of marine fish populations. Harvard University Press, Cambridge, Massachussetts.

SANDFORD, B. P., and S. G. SMITH. 2002. Estimation of smolt-to-adult return percentages for snake river basin anadromous salmonids, 1990-1997. J. Agric. Biol. Environ. Stat., 7: 243-263.

SENSTAD, K. 1990. Hold av stamtorsk. In: Håndbok i Torskeoppdrett; Stamfiskhold og Yngelproduksjon. J. C. Holm, T. Svåsand, and V. Wennevik (eds.). Havforskningsinstituttet, Senter for Havbruk, Bergen, Norway, p. 17-21.

SHIELDS, R. J., N. P. BROWN, and N. R. BROMAGE. 1997. Blastomere morphology as a predictive measure of fish egg viability. Aquaculture, 155: 1-12.

SMITH, T., D. MCVEY, W. JENKINS, M. DENSON, L. HEYWARD, C. SULLIVAN, and D. BERLINSKY. 1999. Broodstock management and spawning of southern flounder, Paralichthys lethostigma. Aquaculture, 176: 87-99.

SOLEMDAL, P. 1973. Transfer of Baltic flatfish to a marine environment and the long term effects on reproduction. Oikos (Suppl.), 15: 268-276.

1997. Maternal effects - a link between the past and the future. J. Sea Res., 37: 213-227.

SOLEMDAL, P., V. MAKHOTIN, and M. FONN. MS 1998. Longterm studies on spawning in ArctoNorwegian cod - mortality pattern of eggs and early larvae. ICES, C.M. Doc., No. 1998/DD:8.

SURESH, A. V., J. B. RUDACILLE, M. L. ALLYN, V. SHEEHAN, R. J. SHEEHAN, and C. C. KOHLER. 
2000. Single injections of human chorionic gonadotropin or mammalian gonadotropin releasing hormone analog at low dosages induce ovulation in white bass. N. Am. J. Aquacult., 62: 87-94.

SVÅSAND, T., A. AJIAD, G. CARVALHO, C. CLEMMENSEN, G. DAHLE, L. HAUSER, W. HUTCHINSON, T. JACOBSEN, O. S. KJESBU, E. MOKSNESS, H. OTTERÅ, H. PAULSEN, D. SCHNACK, P. SOLEMDAL, and A. THORSEN. MS 2000. Demonstration of maternal effects of Atlantic cod: Combining the use of unique mesocosm and novel molecular techniques - A new EU-project. ICES C.M. Doc., No. 2000/R:08.

SVÅSAND, T., K. E. JØRSTAD, H. OTTERÅ, and O. S. KJESBU. 1996. Differences in growth performance between Arcto-Norwegian and Norwegian coastal cod reared under identical conditions. J. Fish Biol., 49: 108-119.

THORPE, J. E., M. S. MILES, and D. S. KEAY. 1984. Developmental rate, fecundity and egg size in Atlantic salmon, Salmo salar L. Aquaculture, 43: 289-305.

THORSEN, A., O. S. KJESBU, H. J. FYHN, and P. SOLEMDAL. 1996. Physiological mechanisms of buoyancy in eggs from brackish water cod. J. Fish Biol., 48: $457-477$.

TARANGER, G., C. HAUX, S. STEFANSSON, B. BJORNSSON, B. WALTHER, and T. HANSEN. 1998. Abrupt changes in photoperiod affect age at maturity, timing of ovulation and plasma testosterone and oestradiol-17 beta profiles in Atlantic salmon, Salmo salar. Aquaculture, 162: 8598.

TRIPPEL, E. A. 1998. Egg size and viability and seasonal offspring production of young Atlantic cod. Trans. Am. Fish. Soc., 127: 339-359.

2003. Estimation of male reproductive success of marine fishes. J. Northw. Atl. Fish. Sci., 33: 81-113 (this volume).

TRIPPEL, E. A., and M. J. MORGAN. 1994a. Age-specific paternal influences on reproductive success in Atlantic cod (Gadus morhua) of the Grand Banks, Newfoundland. ICES Mar. Sci. Symp., 198: 414-422.

1994b. Sperm longevity in Atlantic cod (Gadus morhua). Copeia, 1994: 1025-1029.

TRIPPEL, E. A., J. D. CASTELL, S. R. E. NEIL, and
T. J. BLAIR. 2000. Assessment of egg quality of haddock (Melanogrammus aeglefinus) in paired matings. In: Proceedings of the 6 th international symposium on the reproductive physiology of fish. B. Norberg, O. S. Kjesbu, G. L. Taranger, E. Andersson, and S. O. Steffansson (eds.). Institute of Marine Research and University of Bergen, 4-9 July 1999, p. 405-407.

TRIPPEL, E. A., C. M. DOHERTY, J. WADE, and P. R. HARMON. 1998. Controlled breeding technology for haddock (Melanogrammus aeglefinus) in mated pairs. Bull. Aquacul. Assoc. Can., 98(3): 30-35.

TRIPPEL, E. A., J. J. HUNT, and M.-I. BUZETA. 1995. Evaluation of the cost of reproduction of Georges Bank Atlantic cod (Gadus morhua) using otolith backcalculation. In: Recent developments in fish otolith research. D. H. Secor, J. M. Dean, and S. E. Campana (eds.). University of South Carolina Press, Columbia, SC, p. 599-616.

VALLIN, L., and A. NISSLING. 1998. Cell morphology as an indicator of viability of cod eggs - results from an experimental study. Fish. Res., 38: 247-255.

VALLIN, L., A. NISSLING, and L.WESTIN. 1999. Potential factors influencing reproductive success of Baltic cod, Gadus morhua: A review. Ambio, 28: 92-99.

WATANABE, W. O., P. M. CARROLL, and H. V. DANIELS. 2001. Sustained, natural spawning of southern flounder Paralichthys lethostigma under an extended photothermal regime. J. World Aquacult. Soc., 32: $153-166$.

WILLOUGHBY S. 1999. Manual of salmonid farming. Blackwell Science, [URL http//www.blackwellscience.com], 329 p.

WITTHAMES, P. R., and M. GREER WALKER. 1995. Determinacy of fecundity and oocyte atresia in sole (Solea solea) from the Channel, the North Sea and the Irish Sea. Aquat. Living Res., 8: 91-109.

YARAGINA, N. A, and C. T. MARSHALL. 2000. Trophic influences on interannual and seasonal variation in the liver condition index of Northeast Arctic cod (Gadus morhua). ICES J. Mar. Sci., 57: 42-55.

ZHAO, Y., Y. CHEN, and J. A. BROWN. 2001. Impacts of egg and larval size on survival and growth of Atlantic cod under different feeding conditions. J. Fish Biol., 59: 569-581. 